\title{
Stable carbon isotopic composition of Mytilus edulis shells: relation to metabolism, salinity, $\delta^{13} \mathrm{C}_{\text {DIC }}$ and phytoplankton
}

\author{
David Paul Gillikin a,*, Anne Lorrain ${ }^{\mathrm{b}, 1}$, Steven Bouillon ${ }^{\mathrm{a}}$, \\ Philippe Willenz ${ }^{\mathrm{c}}$, Frank Dehairs ${ }^{\mathrm{a}}$ \\ a Department of Analytical and Environmental Chemistry, Vrije Universiteit Brussel, B-1050 Brussels, Belgium \\ b Section of Petrography-Mineralogy-Geochemistry, Royal Museum for Central Africa, B-3080 Tervuren, Belgium \\ ${ }^{\mathrm{c}}$ Department of Invertebrates, Royal Belgian Institute of Natural Sciences, B-1000 Brussels, Belgium
}

Received 25 August 2005; accepted 6 March 2006

Available online 9 June 2006

\begin{abstract}
Bivalve shells can potentially record the carbon isotopic signature of dissolved inorganic carbon $\left(\delta^{13} \mathrm{C}_{\mathrm{DIC}}\right)$ in estuarine waters, thereby providing information about past estuarine biogeochemical cycles. However, the fluid from which these animals calcify is a 'pool' of metabolic $\mathrm{CO}_{2}$ and external dissolved inorganic carbon (DIC). The incorporation of respired ${ }^{13} \mathrm{C}$ depleted carbon into the skeletons of aquatic invertebrates is well documented, and may affect the $\delta^{13} \mathrm{C}$ record of the skeleton. Typically, less than $10 \%$ of the carbon in the skeleton is metabolic in origin, although higher amounts have been reported. If this small offset is more or less constant, large biogeochemical gradients in estuaries may be recorded in the $\delta^{13} \mathrm{C}$ value of bivalve shells. In this study, it is assessed if the $\delta^{13} \mathrm{C}$ values of Mytilus edulis shells can be used as a proxy of $\delta^{13} \mathrm{C}_{\mathrm{DIC}}$ as well as providing an indication of salinity. First, the $\delta^{13} \mathrm{C}$ values of respired $\mathrm{CO}_{2}\left(\delta^{13} \mathrm{C}_{\mathrm{R}}\right)$ were considered using the $\delta^{13} \mathrm{C}$ values of soft tissues as a proxy for $\delta^{13} \mathrm{C}_{\mathrm{R}}$. Along the strong biogeochemical gradient of the Scheldt estuary (The NetherlandsBelgium), $\delta^{13} \mathrm{C}_{\mathrm{R}}$ was linearly related to $\delta^{13} \mathrm{C}_{\mathrm{DIC}}\left(r^{2}=0.87\right)$, which in turn was linearly related to salinity $\left(r^{2}=0.94\right)$. The mussels were highly selective, assimilating most of their carbon from phytoplankton out of the total particulate organic carbon (POC) pool. However, on a seasonal basis, tissue $\delta^{13} \mathrm{C}$ varied differently than $\delta^{13} \mathrm{C}_{\mathrm{DIC}}$ and $\delta^{13} \mathrm{C}_{\mathrm{POC}}$, most likely due to lipid content of the tissue. All shells contained less than $10 \%$ metabolic carbon, but ranged from near zero to $10 \%$, thus excluding the use of $\delta^{13} \mathrm{C}$ in these shells as a robust $\delta^{13} \mathrm{C}_{\mathrm{DIC}}$ or salinity proxy. As an example, an error in salinity of about 5 would have been made at one site. Nevertheless, large changes in $\delta^{13} \mathrm{C}_{\mathrm{DIC}}(>2 \%)$ can be determined using M. edulis shell $\delta^{13} \mathrm{C}$.
\end{abstract}

(c) 2006 Elsevier Ltd. All rights reserved.

\footnotetext{
* Corresponding author. Present address: Department of Geological Sciences, The State University of New York at New Paltz, 75 South Manheim Boulevard, New Paltz, NY 12561, USA, Tel.: +1322629 1265; fax: +13226293274.

E-mail addresses: david.gillikin@vub.ac.be, david@scientificproofreading.com (D.P. Gillikin).

${ }^{1}$ Present address: IRD, UR THETIS, Centre de Recherche Halieutique, 34203 Sète, France.
}

\section{Introduction}

The stable carbon isotopic composition of dissolved inorganic carbon $\left(\delta^{13} \mathrm{C}_{\text {DIC }}\right)$ in estuarine waters is a valuable tool for tracing the biogeochemical cycling of carbon (Mook and Tan, 1991; 
Hellings et al., 1999; Bouillon et al., 2003). Having past records of $\delta^{13} \mathrm{C}_{\text {DIC }}$ would not only be useful to determine past biogeochemical processing, but would also give insight into anthropogenic pollution (both atmospheric and riverine) (Hellings et al., 2001) and upwelling (Killingley and Berger, 1979). Bivalve shell geochemistry has long been known to reflect the environmental conditions under which the bivalve grew (Epstein et al., 1953; Mook and Vogel, 1968; Mook, 1971; Dettman et al., 2004). Originally, bivalve shell carbonate $\delta^{13} \mathrm{C}$ was believed to track $\delta^{13} \mathrm{C}_{\text {DIC }}$ (Mook and Vogel, 1968; Killingley and Berger, 1979; Arthur et al., 1983). However, more recently it has been proposed that the carbonate skeleton is synthesized from both DIC and organically derived $\mathrm{CO}_{2}$ from internal respiration (Dillaman and Ford, 1982; Swart, 1983; Tanaka et al., 1986; McConnaughey et al., 1997; Furla et al., 2000; Lorrain et al., 2004; and others), which both affect the skeletal stable carbon isotopic signature $\left(\delta^{13} \mathrm{C}_{\mathrm{S}}\right)$. The amount of respired carbon ending up in the skeleton is species specific, with most aquatic animals incorporating less than $10 \%$ (or $<2 \%$ offset from $\delta^{13} \mathrm{C}_{\mathrm{S}}$ equilibrium with $\delta^{13} \mathrm{C}_{\mathrm{DIC}}$ in marine settings) (McConnaughey et al., 1997; Kennedy et al., 2001; Lorrain et al., 2004; Gillikin et al., 2005a), but may reach as high as 35\% (Gillikin, 2005). Therefore, it is of interest to have a better understanding of what controls the $\delta^{13} \mathrm{C}$ value of respired $\mathrm{CO}_{2}$. As there has been much work on the isotope geochemistry of Mytilus edulis shells (Epstein et al., 1953; Mook and Vogel, 1968; Mook, 1971; Tanaka et al., 1986; Vander Putten et al., 2000), this species is the ideal candidate for this study.

The $\delta^{13} \mathrm{C}$ value of respired $\mathrm{CO}_{2}\left(\delta^{13} \mathrm{C}_{\mathrm{R}}\right)$ can be roughly estimated from the tissue $\delta^{13} \mathrm{C}$ value. At the $\mathrm{pH}$ of bivalve body fluids (7-8; Crenshaw, 1972), more than $90 \%$ of $\mathrm{CO}_{2}$ hydrates and ionizes to produce $\mathrm{HCO}_{3}^{-}$, which should be at most $1 \%$ enriched in ${ }^{13} \mathrm{C}$ compared to the respiring tissue (McConnaughey et al., 1997). Yet, considering other processes affecting the $\delta^{13} \mathrm{C}_{\mathrm{R}}$, it has been estimated to be $0.5 \%$ heavier than the tissues on average, but this difference can generally be ignored (McConnaughey et al., 1997). However, a recent study on a zooxanthellate scleractinian coral suggested that $\delta^{13} \mathrm{C}_{\mathrm{R}}$ might not always follow tissue $\delta^{13} \mathrm{C}$ (Swart et al., 2005). The amount of respired $\mathrm{CO}_{2}$ in the skeleton can be approximated using the equation of McConnaughey et al. (1997):
$\mathrm{M}\left(\delta^{13} \mathrm{C}_{\mathrm{R}}\right)+(1-\mathrm{M}) * \delta^{13} \mathrm{C}_{\mathrm{DIC}}=\delta^{13} \mathrm{C}_{\mathrm{S}}-\varepsilon_{\mathrm{cl}-\mathrm{b}}$

where $\mathrm{M}$ is the percent metabolic $\mathrm{CO}_{2}$ contribution and $\varepsilon_{\mathrm{cl}-\mathrm{b}}$ is the enrichment factor between calcite and bicarbonate $(1.0 \pm 0.2 \%$ in Romanek et al., 1992). Other factors may also play a role in determining the $\delta^{13} \mathrm{C}$ value of the internal DIC pool. For example, the enzyme carbonic anhydrase (CA), which catalyses the reaction of bicarbonate to $\mathrm{CO}_{2}$ to facilitate the diffusion of DIC through membranes (Paneth and O'Leary, 1985), may add or remove carbon species from this pool. Activity of CA is known to change with salinity in some bivalves, but is tied to osmoregulation (Henry and Saintsing, 1983). Since M. edulis does not osmoregulate (Newell, 1989), salinity should not affect CA activity in these organisms. Nevertheless, CA activity itself has been shown to be inhibited by $\mathrm{Cl}^{-}$ions (Pocker and Tanaka, 1978). A reduction in CA activity could cause a reduction in environmental DIC entering the animal, resulting in a larger ratio of metabolic DIC and more negative $\delta^{13} \mathrm{C}$ in the calcifying fluid.

Considering that many bivalves incorporate only a small amount of respired $\mathrm{CO}_{2}$, their skeletons should be able to trace large changes in $\delta^{13} \mathrm{C}_{\text {DIC }}$, as was found by Mook and Vogel (1968) and Mook (1971) for M. edulis in the Scheldt estuary (The Netherlands). This is also true if the offset is constant as was found in a freshwater mussel (Kaandorp et al., 2003). Such shell data could then be useful for determining the $\delta^{13} \mathrm{C}_{\text {DIC }}$ and the salinity where the animals grew. Considering that shell $\delta^{13} \mathrm{C}$ values are not dependent on temperature (i.e., the calcite-bicarbonate enrichment factor is independent of temperature between 10 and $40{ }^{\circ} \mathrm{C}$; Romanek et al., 1992), this would also provide a valuable addition to the interpretation of shell $\delta^{18} \mathrm{O}$ profiles, which are dependent on both temperature and salinity, or more precisely, the $\delta^{18} \mathrm{O}$ value of the water (see Gillikin et al., 2005a, for more discussion). Unfortunately, unlike other biogenic carbonates, many minor elements (e.g., $\mathrm{Sr}$ and $\mathrm{Mg}$ ) in bivalves cannot be used to obtain reliable paleoenvironmental information (Stecher et al., 1996; Vander Putten et al., 2000; Gillikin et al., 2005b; Lorrain et al., 2005). Therefore, $\delta^{13} \mathrm{C}_{\mathrm{S}}$ may provide an alternative to estimate salinity and thus allow a better estimation of the $\delta^{18} \mathrm{O}$ value of the water. To evaluate this potential proxy, the $\delta^{13} \mathrm{C}$ values of $M$. edulis shells and mantle tissues, DIC, and particulate organic carbon (POC) were measured 
across a salinity gradient and over 1 year in the Scheldt estuary.

\section{Materials and methods}

Mussels (M. edulis) were collected from the intertidal zone along the salinity gradient of the Scheldt estuary (Westerschelde) from Knokke (KN), Hoofdplaat (HF), Griete (GR) and Ossenisse (OS; the most upstream occurrence of wild Mytilus populations) (Fig. 1) on various dates (see Baeyens et al., 1998 for a general description of the Scheldt estuary). Mussel tissues were sampled on 17 March $(n=3), 3$ May $(n=7)$, and 29 September 2002 $(n=13)$ from $\mathrm{KN}$; on 17 March $(n=5), 3$ May $(n=7), 28$ July $(n=9)$, and 29 September 2002 $(n=16)$ from HF; and on 23 March 2002 from GR $(n=7)$ and OS $(n=12)$. One shell was sampled from KN on 20 February 2003 (shell KN1) and one on 29 September 2002 (shell KN1); from HF on 9 December 2002; from GR on 21 April 2003; and from OS on 9 December 2002 (shell OS1) and 21 April 2003 (shell OS2). It is well known that bivalve shell growth slows in colder weather (e.g., Gillikin et al., 2005a,b); therefore, even the shells sampled after the last water sampling date (November 2002) will mostly correspond to the water sampling period. However, it should be kept in mind that water was sampled over the full year (monthly and bi-weekly in the spring), whereas shell growth probably is highest in spring. Mussels at HF and GR were transplanted from Wemmeldinge (WD; Fig. 1) (see Gillikin et al., 2006, for a more detailed description).

Mantle tissues were collected using a scalpel and were stored frozen $\left(-20^{\circ} \mathrm{C}\right)$. After thawing, tissues were dried in an oven at $60{ }^{\circ} \mathrm{C}$ for $24 \mathrm{~h}$, homogenized with a mortar and pestle, and about $1 \mathrm{mg}$ was placed into a silver cup. Two to three drops of $5 \% \mathrm{HCl}$ were added to decarbonate the sample and the cups were allowed to dry in an oven overnight, after which they were folded closed. Tissue $\delta^{13} \mathrm{C}$ was measured on an Elemental Analyzer (Flash 1112 EA ThermoFinnigan) coupled via a CONFLO III to a ThermoFinnigan Delta ${ }^{\text {plus }} \mathrm{XL}$ isotope ratio mass spectrometer (IRMS). Using this same instrument and method, Verheyden et al. (2004) report a long-term analytical precision for $\delta^{13} \mathrm{C}$ of $0.08 \%$ on 214 analyses of the IAEA-CH-6 standard $(1 \sigma)$.

Shells were sectioned along the axis of major growth and samples were drilled from the calcite layer along the growth-time axis every $300 \mu \mathrm{m}$ using a Merchantek MicroMill and $300 \mu \mathrm{m}$ drill bit. Although $M$. edulis has both calcite and aragonite shell layers, the aragonite layer is not suitable for time resolved sampling (see Vander Putten et al., 2000). Carbonate powders were reacted in a Kiel

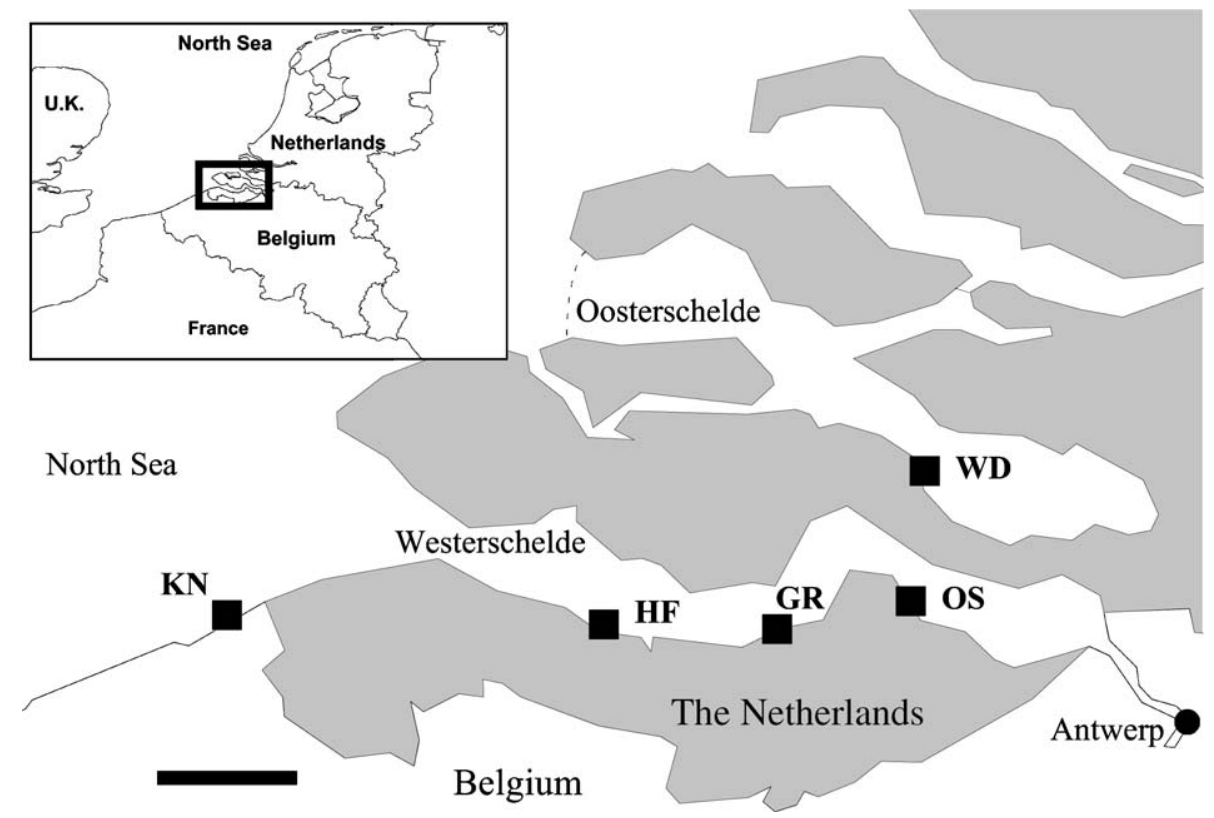

Fig. 1. Map of the Westerschelde estuary (referred to as the Scheldt estuary in the text). The four study sites are indicated Knokke (KN), Hoofdplaat (HF), Griete (GR), and Ossenisse (OS). Scale bar $=10 \mathrm{~km}$. Wemmeldinge (WD) is also shown. 
III coupled to a ThermoFinnigan Delta ${ }^{\text {plus }}$ XL dual inlet IRMS with a long-term $\delta^{13} \mathrm{C}$ precision of $0.039 \%$ on the NBS-19 standard $\left(\delta^{13} \mathrm{C}=+1.95 \%\right.$, $n=292)$ and $0.068 \%$ on the NBS-18 standard $\left(\delta^{13} \mathrm{C}=-5.04 \%, n=22\right)$. More details regarding the treatment of these shells can be found in Gillikin et al. (2006).

Near-shore water was sampled during high tide at least monthly from November 2001 to November 2002 for salinity, chlorophyll $a$ concentrations (Chl a), $\delta^{13} \mathrm{C}_{\mathrm{DIC}}, \delta^{13} \mathrm{C}_{\mathrm{POC}}$, and suspended particulate matter (SPM). Water temperature was monitored hourly at each site using an Onset TidBit data logger (from November 2001 to May 2003) (Fig. 2). Salinity was measured in situ with a WTW multiline P4 multimeter. Chlorophyll $a$ concentrations were determined by filtering $200-500 \mathrm{ml}$ of seawater through Whatman GF-F filters in the field. Filters were wrapped in aluminum foil and placed in liquid nitrogen; three replicate filters per site were taken on each sampling date. In the laboratory, samples were transferred to a $-85^{\circ} \mathrm{C}$ freezer until analysis at NIOO-CEME, Yerseke, NL, using reverse-phase HPLC (Gieskes et al., 1988) with a reproducibility of $2.7 \%$ (or $0.3 \mu \mathrm{g} / \mathrm{l} ; 1 \sigma$ ) for Chl $a$ (based on an in-house standard, $n=7)$. The $\delta^{13} \mathrm{C}_{\text {DIC }}$ was determined by acidifying $5 \mathrm{ml}$ of water in an $8 \mathrm{ml}$ helium-flushed headspace vial, followed by overnight equilibration, and subsequently injecting $400 \mu \mathrm{l}$ of the headspace into the carrier gas stream of the continuous flow EA-IRMS. Precision of $\delta^{13} \mathrm{C}_{\text {DIC }}$ was better than $0.2 \%$ based on replicate measurements; data were corrected using calibrated $\mathrm{CO}_{2}$ gas according to Miyajima et al. (1995) (see Gillikin et al., 2005a; Gillikin, 2005). To approximate the $\delta^{13} \mathrm{C}$ value of phytoplankton, $20 \%$ was subtracted from the $\delta^{13} \mathrm{C}_{\text {DIC }}$ values $\left(\delta^{13} \mathrm{C}_{\text {DIC-20 }}\right.$; see Section 4). The $\delta^{13} \mathrm{C}_{\text {POC }}$ was measured following

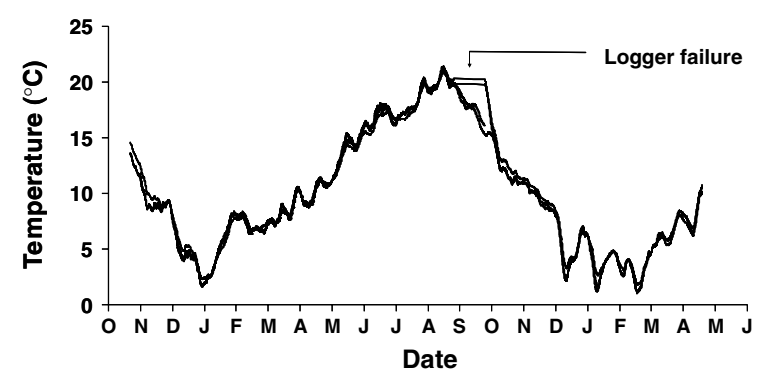

Fig. 2. Water temperature recorded hourly using Onset TidBit dataloggers at all four sites. The weekly running average is shown from October 2001 to May 2003. The loggers failed at GR and HF for about a month as is indicated on the graph.
Lorrain et al. (2003). Briefly, 200-500 $\mathrm{ml}$ of seawater were filtered through Whatman GF-F filters, which were dried at $50^{\circ} \mathrm{C}$, weighed, fumed in $\mathrm{HCl}$ vapors, wrapped in silver cups and analyzed on the EA-IRMS described above. Concentrations of SPM are based on the dry weights of these filters.

\section{Results}

The strong salinity gradient of the Scheldt is obvious from the data presented in Fig. 3. There is a significant positive linear relationship between $\delta^{13} \mathrm{C}_{\text {DIC }}$ and salinity, with $\delta^{13} \mathrm{C}_{\text {DIC }}=$ Salinity *0.39 $( \pm 0.03)-13.71( \pm 0.57) \quad\left(r^{2}=0.94, \quad p<\right.$ $0.0001, n=63$; for the salinity range of $\sim 5-30$ ) (Fig. 4).

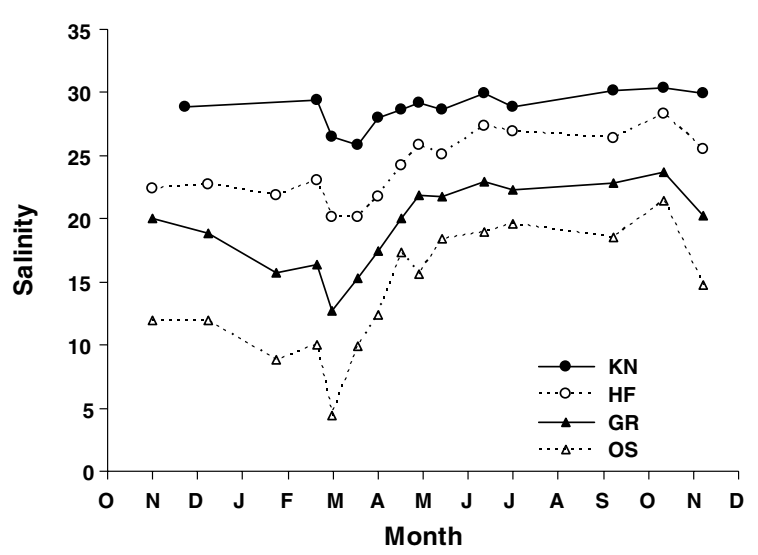

Fig. 3. Salinity at the four Scheldt sites measured over 1 year (November 2001 to November 2002).

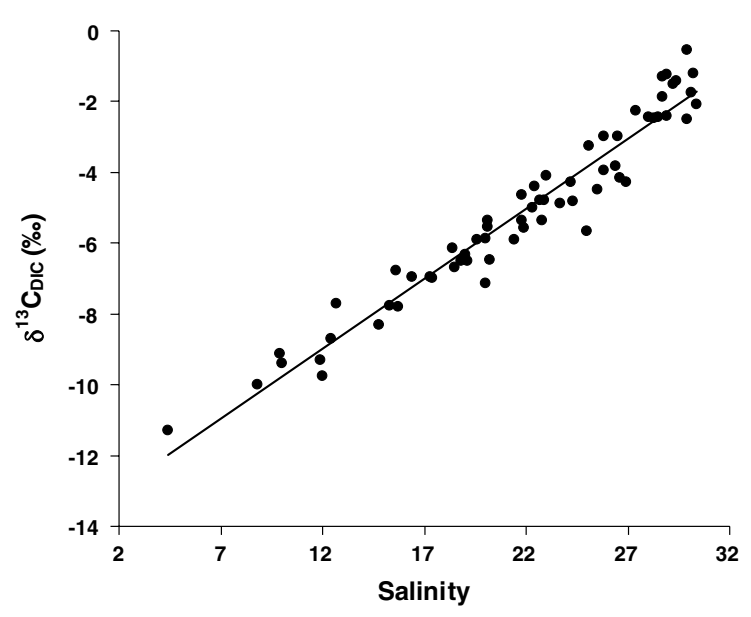

Fig. 4. $\delta^{13} \mathrm{C}_{\mathrm{DIC}}$ versus salinity from samples taken over 1 year at the four sites along the Scheldt estuary $\left(r^{2}=0.94, p<0.0001\right)$. 


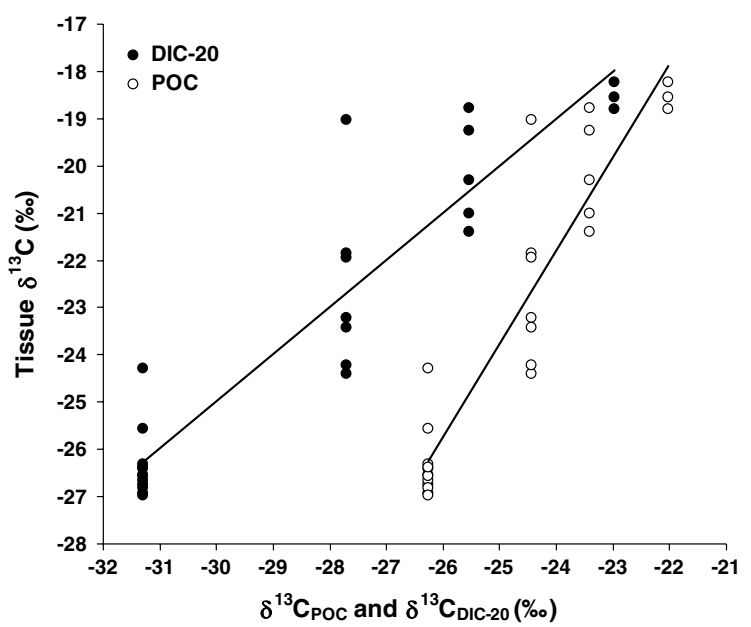

Fig. 5. Linear regressions between mantle tissue $\delta^{13} \mathrm{C}$ and both $\delta^{13} \mathrm{C}_{\mathrm{POC}}$ (open symbols) and $\delta^{13} \mathrm{C}_{\mathrm{DIC}-20}$ (solid symbols) (in \%o) from mussels collected at all four sites in March 2002. $n=27$ for each.

There were strong linear relationships between mantle tissue and both $\delta^{13} \mathrm{C}_{\mathrm{POC}}$ and $\delta^{13} \mathrm{C}_{\mathrm{DIC}-20}$ for samples collected from all four sites in March 2002 (Fig. 5). The relationships are: Tissue $\delta^{13} \mathrm{C}=$ $0.99( \pm 0.16) * \delta^{13} \mathrm{C}_{\text {DIC-20 }}+4.89( \pm 4.48) \quad\left(r^{2}=0.87\right.$, $n=27, \quad p<0.0001)$ and Tissue $\delta^{13} \mathrm{C}=1.97( \pm$ $0.31) * \delta^{13} \mathrm{C}_{\mathrm{POC}}+25.39( \pm 7.87)\left(r^{2}=0.87, n=27\right.$, $p<0.0001) . \quad \delta^{13} \mathrm{C}_{\mathrm{POC}}$ and $\delta^{13} \mathrm{C}_{\mathrm{DIC}}$ were also significantly correlated $\left(\delta^{13} \mathrm{C}_{\mathrm{POC}}=0.42( \pm 0.09) *\right.$ $\delta^{13} \mathrm{C}_{\mathrm{DIC}}-21.0( \pm 0.5) ; \quad r^{2}=0.61, \quad n=59, \quad p<$ $0.0001)$. The slope of the relationship between mantle tissue and $\delta^{13} \mathrm{C}_{\text {DIC-20 }}$ was not significantly different from one $(p<0.0001)$. SPM was generally high at all four sites (range $=13-550 \mathrm{mg} / 1$, mean $=$ $86 \mathrm{mg} / \mathrm{l})$.

Mantle tissue $\delta^{13} \mathrm{C}$ varied considerably throughout the year at $\mathrm{HF}$ and $\mathrm{KN}$, with a $2-3 \%$ decrease between March and September 2002 (Fig. 6). At both sites, mantle tissue was least negative in March, just before the phytoplankton bloom (as indicated by the Chl $a$ data), but was more similar to the $\delta^{13} \mathrm{C}$ of potential food sources (i.e., $\delta^{13} \mathrm{C}_{\text {DIC-20 }}$ in May, July, and September.

High resolution $\delta^{13} \mathrm{C}_{\mathrm{S}}$ data are provided in Fig. 7 and are discussed in more detail in Gillikin et al. (2006). The average annual shell $\delta^{13} \mathrm{C}$ is compared with the average annual $\delta^{13} \mathrm{C}_{\text {DIC }}$ at each site in Fig. 8 along with the predicted equilibrium calcite based on the $\varepsilon_{\mathrm{cl}-\mathrm{b}}$ from Romanek et al. (1992). Average shell and DIC $\delta^{13} \mathrm{C}$ are presented in Table 1 along with average salinity and metabolic $\mathrm{C}$ con- tribution to the shell. With the exception of the two shells from $\mathrm{KN}$, shells were on average in equilibrium with $\delta^{13} \mathrm{C}_{\text {DIC }}$ (Fig. 8).

\section{Discussion}

\subsection{Metabolic carbon sources}

Although it is well established that the carbon isotope fractionation between phytoplankton and DIC is variable (Rau et al., 1992; Hinga et al., 1994; Boschker et al., 2005), a value between $18 \%$ and $22 \%$ is often used as an estimate (Cai et al., 1988; Hellings et al., 1999; Fry, 2002; Bouillon et al., 2004). Therefore, similar to Fry (2002), an average value of $20 \%$ is used in this study. From Fig. 5 it is clear that M. edulis is a highly selective feeder, as the slope between the expected $\delta^{13} \mathrm{C}$ of phytoplankton (i.e., $\delta^{13} \mathrm{C}_{\text {DIC-20 }}$ ) and tissues is not significantly different from one, whereas the slope between $\delta^{13} \mathrm{C}$ of tissues and $\delta^{13} \mathrm{C}_{\mathrm{POC}}$ was far from one (slope $=2.0 \pm 0.3$ ). The suspended POC pool is a mixture of different sources of carbon, each with an often distinct $\delta^{13} \mathrm{C}$ value, such as phytoplankton, terrestrial carbon (in general, $\sim-27 \%$ from $\mathrm{C} 3$ plants and $\sim-14 \%$ from C4 plants; Mook and Tan, 1991), resuspended sediments (Scheldt: $\sim-19$ to $-24 \%$; Middelburg and Nieuwenhuize, 1998; Herman et al., 2000), marine macro-algae detritus (Scheldt: green algae $\sim-17 \%$, brown algae $\sim-25 \%$; Gillikin unpublished data), microphytobenthos (Scheldt: $\sim-15 \%$; Middelburg et al., 2000; Herman et al., 2000), and other components from which the mussels must select. As our samples were taken near the shore, there was probably a large amount of suspended sediments, which is indicated by the high SPM content. Particle selection can occur both at the gills (pre-ingestive) and in the gut (post-ingestive) (reviewed in Ward and Shumway, 2004), but using $\delta^{13} \mathrm{C}$ as a tracer deals only with assimilated carbon. Moreover, using the selectivity equation from Bouillon et al. (2004),

$$
\begin{aligned}
\text { Selectivity }= & \left(\Delta \delta^{13} \mathrm{C}_{\text {tissue }}-\Delta \delta^{13} \mathrm{C}_{\mathrm{POC}} / \Delta \delta^{13} \mathrm{C}_{\mathrm{DIC}}\right. \\
& \left.-\Delta \delta^{13} \mathrm{C}_{\mathrm{POC}}\right) * 100[\%]
\end{aligned}
$$

where $\Delta$ is the overall estuarine gradient in tissue, POC and DIC $\delta^{13} \mathrm{C}$ values (assumes that selectivity is similar at all stations, see Bouillon et al., 2004), suggests that the mussels are $\sim 90 \%$ selective, which further illustrates that they assimilate their carbon primarily from phytoplankton, which in turn 

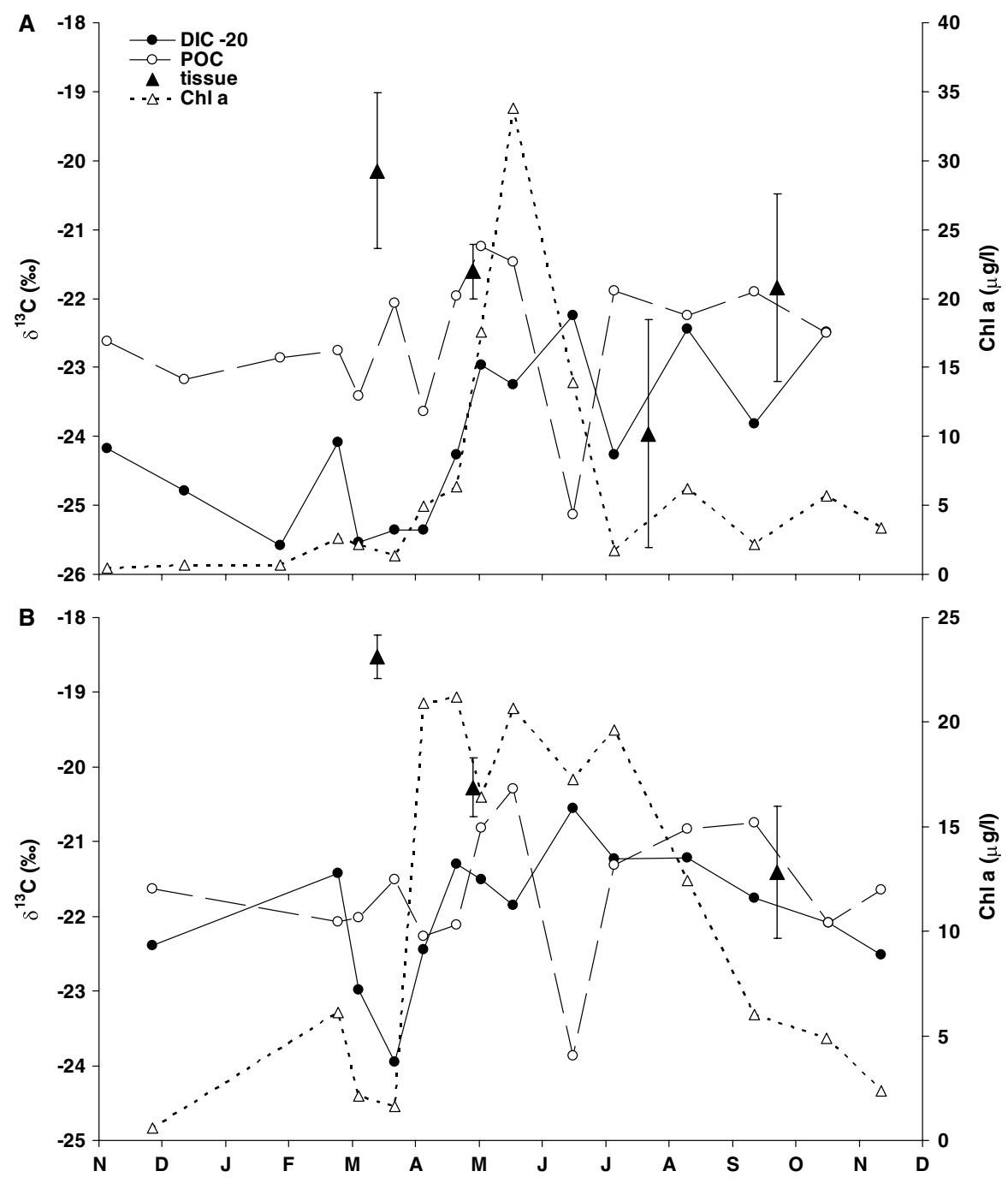

Fig. 6. Temporal variations in mantle tissue $\delta^{13} \mathrm{C}, \delta^{13} \mathrm{C}_{\mathrm{POC}}, \delta^{13} \mathrm{C}_{\mathrm{DIC}-20}$ (in \%o), and chlorophyll $a$ for Hoofdplaat (A) and $\mathrm{Knokke}(\mathrm{B})$ for the period November 2001 to November 2002. Error bars represent standard deviations.

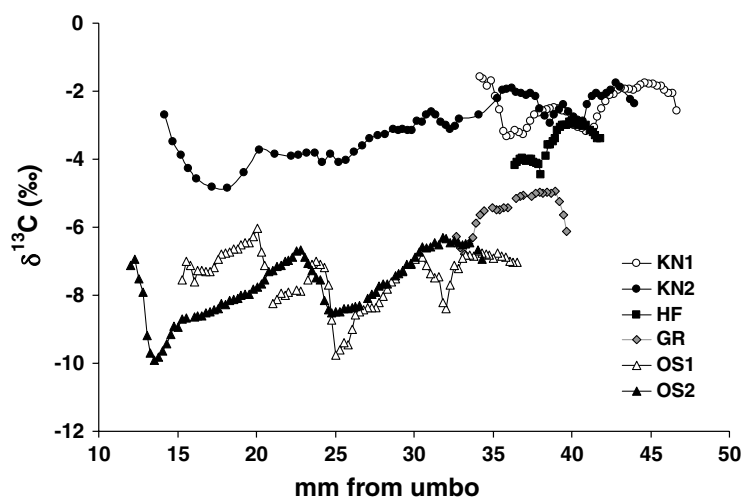

Fig. 7. High resolution $\delta^{13} \mathrm{C}$ shell data from the six shells plotted versus distance from the umbo (growth direction is from left to right). See Fig. 1 for site codes. obtains its carbon from the DIC pool. It is generally accepted that the $\delta^{13} \mathrm{C}$ value of an organism reflects the $\delta^{13} \mathrm{C}$ value of its diet, with little $\left(\Delta \delta^{13} \mathrm{C}=+1 \%\right)$ or no change (DeNiro and Epstein, 1978; Fry and Sherr, 1984). However, extreme values are not uncommon with some $\Delta \delta^{13} \mathrm{C}$ values being greater than $+3 \%$ o (Post, 2002; McCutchan et al., 2003). Therefore, the intercept of the regression between tissue $\delta^{13} \mathrm{C}$ and phytoplankton $\delta^{13} \mathrm{C}\left(\delta^{13} \mathrm{C}_{\text {DIC-20 }}\right)$ should be +1 . Nevertheless, it should be kept in mind that the $20 \%$ fractionation used in this paper is a rough estimate. The intercept of $4.89 \pm 4.48 \%$ o in our dataset (Fig. 5) can therefore be explained by an extreme fractionation factor between mussel tissue and phytoplankton, an error in the phyto- 


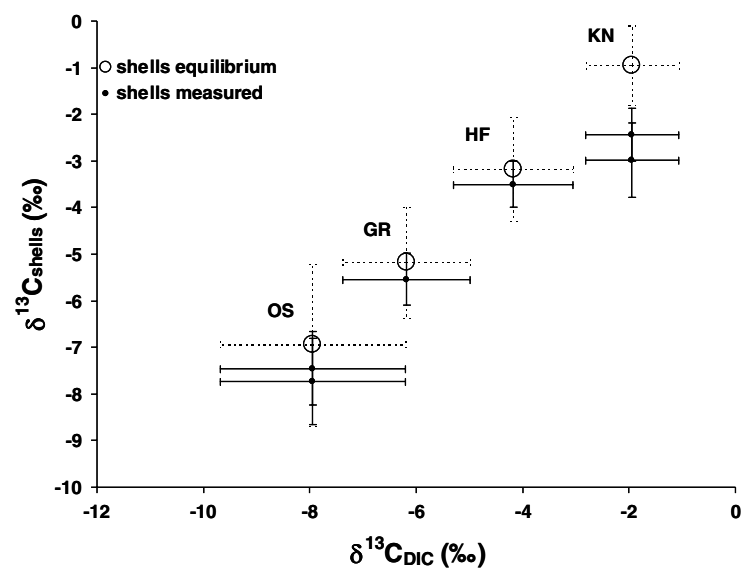

Fig. 8. Mean $\delta^{13} \mathrm{C}_{s}$ and $\delta^{13} \mathrm{C}_{\mathrm{DIC}}$ (in \%o) averaged over the full year for the four sites (noted above data points, see Fig. 1 for description of site codes). Also plotted are the expected shell values based on the fractionation factor between $\delta^{13} \mathrm{C}_{\text {DIC }}$ and calcite $(+1.0 \%$; Romanek et al., 1992). Error bars represent standard deviations.

plankton fractionation used, and/or by individual variation in tissue $\delta^{13} \mathrm{C}$. Moreover, errors in this simplified model can arise from the mussels feeding on food items other than phytoplankton. Mussels have been shown to feed on dissolved organic carbon (DOC) (Roditi et al., 2000), their own and other bivalve larvae (Lehane and Davenport, 2004), zooplankton (Lehane and Davenport, 2002; Wong et al., 2003), and macroalgae detritus (Levinton et al., 2002); all with different $\delta^{13} \mathrm{C}$ values (see above). Nevertheless, as a first approximation, $\delta^{13} \mathrm{C}_{\mathrm{R}}$ values should roughly mirror $\delta^{13} \mathrm{C}$ values, which in turn should be linearly correlated with $\delta^{13} \mathrm{C}_{\mathrm{DIC}}$ values, as has been noticed in other bivalves (e.g., Fry, 2002). However, Swart et al. (2005) found that $\delta^{13} \mathrm{C}_{\mathrm{R}}$ from a coral deviated significantly from the $\delta^{13} \mathrm{C}$ of tissues (both positive and negative devi- ations of up to $3 \%$ ), which they attributed to different compounds (e.g., lipids) being respired at various times of the year.

It is evident that the relationship between tissue $\delta^{13} \mathrm{C}$ and $\delta^{13} \mathrm{C}_{\text {DIC }}$ found in March (Fig. 5) does not necessarily hold true for the whole year (Fig. 6). This could be attributed to changing food sources, such as resuspended benthic algae, or variable fractionation between phytoplankton and DIC throughout the year. Indeed, Boschker et al. (2005) found that DIC - diatom fractionation varied from about $16 \%$ to $24 \%$ along this same estuary. Other factors such as temperature and phytoplankton growth rate can also influence the fractionation between phytoplankton and DIC (see Savoye et al., 2003). However, a more likely explanation is changing lipid levels in M. edulis tissues. In this species, the mantle contains much of the gonad (Morton, 1992); and in this region, M. edulis spawning peaks when temperatures exceed approximately $10^{\circ} \mathrm{C}$ (Hummel et al., 1989). At all four sites this occurs in mid-March (Fig. 2), approximately at the same time as the tissue samples were collected. As a result of spawning, the tissues would have a lower lipid content (see de Zwaan and Mathieu, 1992). Since lipids have a lighter $\delta^{13} \mathrm{C}$ signal than other biochemical components (Abelson and Hoering, 1961; Tieszen et al., 1983; Focken and Becker, 1998) and since the mantle exhibits a sharp drop in lipid content just after spawning (de Zwaan and Mathieu, 1992), the more positive tissue $\delta^{13} \mathrm{C}$ values observed for March can be explained. After the phytoplankton bloom, which begins in April or May, tissue lipid reserves would be restored, thus lowering the $\delta^{13} \mathrm{C}$ value. Indeed, Lorrain et al. (2002) found that $\delta^{13} \mathrm{C}$ of scallop tissues were highest in spring when lipids were low, and decreased as lipids accumulated toward late summer. In the shells, however,

Table 1

Average shell and water $\delta^{13} \mathrm{C}$ data, predicted minus measured $\delta^{13} \mathrm{C}_{\mathrm{S}}$ (pred-meas, in \%o) and percent metabolic $\mathrm{C}$ incorporation $(\% \mathrm{M})$ in $M$. edulis shells at each site

\begin{tabular}{|c|c|c|c|c|c|c|}
\hline Shell & KN1 & $\mathrm{KN} 2$ & $\mathrm{HF}$ & GR & OS1 & OS2 \\
\hline Average $\delta^{13} \mathrm{C}_{\mathrm{S}}(\% \mathrm{o})$ & -2.98 & -2.43 & -3.50 & -5.54 & -7.45 & -7.73 \\
\hline $\mathrm{SD} \delta^{13} \mathrm{C}_{\mathrm{S}}(\%)$ & 0.79 & 0.57 & 0.49 & 0.56 & 0.80 & 0.92 \\
\hline$n \delta^{13} \mathrm{C}_{\mathrm{S}}$ & 68 & 57 & 35 & 26 & 80 & 86 \\
\hline$\delta^{13} \mathrm{C}_{\text {DIC }}(\%)$ & -1.9 & -1.9 & -4.0 & -6.2 & -7.9 & -7.9 \\
\hline $\mathrm{SD} \delta^{13} \mathrm{C}_{\mathrm{DIC}}(\%)$ & 0.9 & 0.9 & 1.2 & 1.2 & 1.7 & 1.7 \\
\hline$n \delta^{13} \mathrm{C}_{\text {DIC }}$ & 15 & 15 & 15 & 15 & 16 & 16 \\
\hline Salinity & 29 & 29 & 25 & 20 & 14 & 14 \\
\hline Pred-meas $(\%)$ & 2.04 & 1.49 & 0.33 & 0.36 & 0.51 & 0.79 \\
\hline$\% \mathrm{M}$ & 10.9 & 8.0 & 1.8 & 2.3 & 3.0 & 4.7 \\
\hline
\end{tabular}

$\% \mathrm{M}$ was calculated using average data and the equation of McConnaughey et al. (1997, see text). 
the spawning period is reflected by more negative $\delta^{13} \mathrm{C}_{\mathrm{S}}$ values (see Gillikin et al., 2006), although the $\delta^{13} \mathrm{C}_{\text {DIC }}$ is generally becoming more positive (Fig. 6). This could be explained by higher metabolic rates just after spawning, as energy lost during spawning is restored. Vander Putten et al. (2000) also described these patterns in $\delta^{13} \mathrm{C}_{\mathrm{S}}$ in $M$. edulis from the Scheldt as being a result of increased respiration associated with periods of higher food availability.

\subsection{Shell carbon isotopic signature}

There are several hypotheses that try to explain disequilibrium isotopic fractionation (or vital effects) in biological carbonates. The two leading hypotheses are the "kinetic" model (McConnaughey, 1989a,b) and the "carbonate" model (Adkins et al., 2003), which each lead to disequilibrium of both $\delta^{13} \mathrm{C}$ and $\delta^{18} \mathrm{O}$ (reviewed in Shanahan et al., 2005). As bivalves are known to precipitate in oxygen isotopic equilibrium (Epstein et al., 1953; Chauvaud et al., 2005), these effects do not seem to be acting on bivalve carbonates.

In order to compare the $\delta^{13} \mathrm{C}_{\text {DIC }}$ with shell $\delta^{13} \mathrm{C}$, the shell data must be assigned calendar dates. Typically, the $\delta^{18} \mathrm{O}$ signal in the shell can be used to date the samples, based on the marked winter-summer temperature contrast (e.g., Klein et al., 1996; Gillikin et al., 2005a); however, this was difficult with these samples due to the large salinity influence (more precisely, the $\delta^{18} \mathrm{O}$ of the water) on the $\delta^{18} \mathrm{O}$ signal in shells from upstream sites (data presented in Gillikin et al., 2006). The $\delta^{18} \mathrm{O}$ signal from the $\mathrm{KN}$ shells had a clear periodicity indicating that a full year was sampled. Shells from HF and GR were stained with calcein (October 01; see Gillikin et al., 2006) and cover a full year, but growth seems reduced. Shells from OS were each sampled along $2 \mathrm{~cm}$ of growth ( $\sim 15-35 \mathrm{~mm}$ from umbo), so represent at least 1 year of growth. Therefore, the average annual shell $\delta^{13} \mathrm{C}$ was compared with the average annual $\delta^{13} \mathrm{C}_{\text {DIC }}$ at each site (Fig. 8).

Despite the variability in tissue $\delta^{13} \mathrm{C}$ throughout the year, the mean shell values closely match equilibrium values $\left(\delta^{13} \mathrm{C}_{\mathrm{DIC}}+1 \%\right.$; Romanek et al., 1992) for three of the four sites (Fig. 8). The differences between measured and predicted values vary between sites (Table 1), with salinity apparently having little to do with disequilibrium as would be expected if the enzyme CA was responsible for changing the $\delta^{13} \mathrm{C}$ value of the internal DIC pool (see Section 1). Nevertheless, all shells generally fall within the $10 \%$ metabolic $\mathrm{C}$ incorporation suggested to be typical for aquatic marine invertebrates by McConnaughey et al. (1997) (Table 1).

Although $\delta^{13} \mathrm{C}_{\mathrm{R}}$ does not seem to largely affect the $\delta^{13} \mathrm{C}_{\mathrm{S}}\left(\sim<10 \%\right.$ incorporation of metabolic $\mathrm{CO}_{2}$ into the shell), the variability in the percent incorporated is enough to preclude its use as a robust $\delta^{13} \mathrm{C}_{\text {DIC }}$ proxy, and hence a salinity proxy. For example, if the $\delta^{13} \mathrm{C}_{\mathrm{S}}$ values of the seaward $\mathrm{KN}$ shells were used to predict $\delta^{13} \mathrm{C}_{\text {DIC }}$ and salinity, one would conclude that this shell came from a site similar to HF (Fig. 8), even though the difference in salinity between these sites is typically around 5 . From Fig. 8, it may seem that mussel shells from the same environment could be used to determine $\delta^{13} \mathrm{C}_{\text {DIC }}$, but another study has shown that Mercenaria mercenaria shells collected from similar environments had very different metabolic contributions to their shells (Gillikin, 2005), suggesting this might not generally be the case. The reason why the $\mathrm{KN}$ shells were farther from equilibrium than the others could be linked to higher metabolic rates caused by the stronger wave action at this site, which increases water flow and thus food availability. Moderate wave action has been shown to increase growth rates and condition values in Mytilus (Steffani and Branch, 2003), which would lead to higher metabolic rates. There are also other possibilities which can increase metabolic rate, such as epibiont cover (e.g., barnacles (Buschbaum and Saier, 2001) which are more abundant at the KN site), exposure to predators (Frandsen and Dolmer, 2002), and pollution (Wang et al., 2005).

An alternative explanation for the higher metabolic $\mathrm{C}$ incorporation in shells at the $\mathrm{KN}$ site may be the differences in the ambient $\mathrm{CO}_{2} / \mathrm{O}_{2}$ ratios. McConnaughey et al. (1997) describe a simple respiratory gas exchange model, where the inward flux of environmental $\mathrm{CO}_{2}$ dilutes the $\mathrm{CO}_{2}$ produced internally by respiration (see also Shanahan et al., 2005). In this model, the ambient $\mathrm{CO}_{2} / \mathrm{O}_{2}$ ratios and blood $\mathrm{O}_{2}$ /ambient $\mathrm{O}_{2}$ ratios control the amount of respired $\mathrm{CO}_{2}$ in the tissues and precipitating carbonates of the bivalve. With higher ambient $\mathrm{CO}_{2} / \mathrm{O}_{2}$ ratios there is more flushing of $\mathrm{CO}_{2}$ produced internally by respiration. The Scheldt estuary is known to have particularly high $\mathrm{pCO}_{2}$ values (Frankignoulle et al., 1998). The $\mathrm{pCO}_{2}$ and $\mathrm{pO}_{2}$ data collected in the Scheldt estuary in July 2000 by Frankignoulle and Borges (2001) indeed show that the upstream sites have higher ambient $\mathrm{CO}_{2} / \mathrm{O}_{2}$ 
ratios (ranging from 0.11 at $\mathrm{HF}$ to 0.22 at $\mathrm{OS}$ ) as compared to a site with salinity similar to the $\mathrm{KN}$ site $(\sim 0.06)$. However, if this was the main factor controlling the amount of metabolic $\mathrm{C}$ incorporation into the shells, then a steady increase would be expected from low salinity (OS) to high salinity $(\mathrm{KN})$, which was not observed in our data (Table 1).

The difference between the results presented here and those from earlier studies for the same species and estuary (i.e., Mook and Vogel, 1968; Mook, 1971), which state that $\delta^{13} \mathrm{C}_{\mathrm{S}}$ is a good proxy of $\delta^{13} \mathrm{C}_{\mathrm{DIC}}$, can be explained by three main considerations. First, these earlier authors analyzed mixtures of aragonite and calcite from the shells, which differ greatly in equilibrium $\delta^{13} \mathrm{C}$ values with $\mathrm{HCO}_{3}^{-}$(i.e., $+1 \%$ for calcite and $+2.7 \%$ for aragonite; Romanek et al., 1992). Second, they roasted their samples and found significant differences between roasted and non-roasted $\delta$-values, while Vander Putten et al. (2000) found no difference in calcite due to roasting samples from this same species, indicating a possible isotopic alteration in these earlier studies. Finally, these earlier studies did not consider metabolic effects, and perhaps did not sample populations with markedly different metabolic rates.

In conclusion, although $\delta^{13} \mathrm{C}_{\mathrm{R}}$ values can closely follow $\delta^{13} \mathrm{C}_{\text {DIC }}$ values, and although the percentage of metabolic $\mathrm{C}$ incorporated into the shells of $M$. edulis is low, the variability in metabolic $\mathrm{C}$ incorporation is too high to allow confident $\delta^{13} \mathrm{C}_{\text {DIC }}$ and salinity determinations based on $\delta^{13} \mathrm{C}_{\mathrm{S}}$. The data presented here could not be used to differentiate between sites with a salinity difference of 5 , which in terms of $\delta^{18} \mathrm{O}$ paleothermometry would correspond to about $4{ }^{\circ} \mathrm{C}$ at these sites (Gillikin, 2005). Thus, $\delta^{13} \mathrm{C}_{\mathrm{S}}$ is not a robust proxy of environmental conditions in M. edulis calcite, but may be useful for assessing metabolic differences between different populations, and can nevertheless be used as an indicator of large $\delta^{13} \mathrm{C}_{\text {DIC }}$ (and salinity) differences. It remains possible that samples from within the estuary proper, or samples from the same site, may have similar metabolic contributions to the shell $\delta^{13} \mathrm{C}$ and therefore could provide a better indication of changes in $\delta^{13} \mathrm{C}_{\text {DIC }}$ through time; however, more samples from the same site are needed to test this hypothesis.

\section{Acknowledgements}

We are much indebted to V. Mubiana for assistance with mussel collection and setting up the field experiment. A. Van de Maele and M. Korntheuer both assisted with keeping the Kiel III operational; and $\mathrm{A}$. Borges kindly provided $\mathrm{pCO}_{2}$ and $\mathrm{O}_{2}$ data from the Scheldt. Constructive criticism, which greatly improved this manuscript, was given by $\mathrm{T}$. McConnaughey, M.D. Delafontaine, M.E. Böttcher (guest editor), and A. Verheyden. S.B. is funded by a postdoctoral mandate of the FWO-Flanders. Funding was provided by the Belgian Federal Science Policy Office, Brussels, Belgium (CALMARS, contract: EV/03/04B) and the ESF Paleosalt project funded by the FWO-Flanders (contract: G.0642.05).

\section{References}

Abelson, P.H., Hoering, T.C., 1961. Carbon isotope fractionation in the formation of amino acids by photosynthetic organisms. Proceedings of the National Academy of Sciences 47, 623-632.

Adkins, J.F., Boyle, E.A., Curry, W.B., Lutringer, A., 2003. Stable isotopes in deep-sea corals and a new mechanism for "vital effects". Geochimica et Cosmochimica Acta 67, 11291143.

Arthur, M.A., Williams, D.F., Jones, D.S., 1983. Seasonal temperature-salinity changes and thermocline development in the mid-Atlantic Bight as recorded by the isotopic composition of bivalves. Geology 11, 655-659.

Baeyens, W., van Eck, B., Lambert, C., Wollast, R., Goeyens, L., 1998. General description of the Scheldt estuary. Hydrobiologia 366, 1-14.

Boschker, H.T.S., Kromkamp, J.C., Middelburg, J.J., 2005. Biomarker and carbon isotopic constraints on bacterial and algal community structure and functioning in a turbid, tidal estuary. Limnology and Oceanography 50, 70-80.

Bouillon, S., Frankignoulle, M., Dehairs, F., Velimirov, B., Eiler, A., Abril, G., Etcheber, H., Borges, A.V., 2003. Inorganic and organic carbon biogeochemistry in the Gautami Godavari estuary (Andhra Pradesh, India) during pre-monsoon: the local impact of extensive mangrove forests. Global Biogeochemical Cycles 17, 1114. doi:10.1029/2002GB002026.

Bouillon, S., Koedam, N., Baeyens, W., Satyanarayana, B., Dehairs, F., 2004. Selectivity of subtidal benthic invertebrate communities for local microalgal production in an estuarine mangrove ecosystem during the post-monsoon period. Journal of Sea Research 51, 133-144.

Buschbaum, C., Saier, B., 2001. Growth of the mussel Mytilus edulis L. in the Wadden Sea affected by tidal emergence and barnacle epibionts. Journal of Sea Research 45, 2736.

Cai, D.L., Tan, F.C., Edmond, J.M., 1988. Sources and transport of particulate organic carbon in the Amazon River and estuary. Estuarine, Coastal and Shelf Science 26, 1-14.

Chauvaud, L., Lorrain, A., Dunbar, R.B., Paulet, Y.-M., Thouzeau, G., Jean, F., Guarini, J.-M., Mucciarone, D., 2005. The shell of the Great Scallop Pecten maximus as a high frequency archive of paleoenvironmental change. Geochemistry, Geophysics, Geosystems 6, Q08001. doi:10.1029/ 2004GC000890. 
Crenshaw, M.A., 1972. Inorganic composition of molluscan extrapallial fluid. Biological Bulletin 143, 506-512.

de Zwaan, A., Mathieu, M., 1992. Cellular biochemistry and endochrinology. In: Gosling, E. (Ed.), The Mussel Mytilus: Ecology, Physiology, Genetics and Culture, Developments in Aquaculture and Fisheries Science, vol. 25. Elsevier, pp. 223307.

DeNiro, M., Epstein, S., 1978. Influence of diet on the distribution of carbon isotopes in animals. Geochimica et Cosmochimica Acta 42, 495-506.

Dettman, D.L., Flessa, K.W., Roopnarine, P.D., Schöne, B.R., Goodwin, D.H., 2004. The use of oxygen isotope variation in shells of estuarine mollusks as a quantitative record of seasonal and annual Colorado River discharge. Geochimica et Cosmochimica Acta 68, 1253-1263.

Dillaman, R.M., Ford, S.E., 1982. Measurement of calciumcarbonate deposition in mollusks by controlled etching of radioactively labeled shells. Marine Biology 66, 133-143.

Epstein, S., Buchsbaum, R., Lowenstam, H.A., Urey, H.C., 1953. Revised carbonate - water isotopic temperature scale. Bulletin of the Geological Society of America 64, 1315-1326.

Focken, U., Becker, K., 1998. Metabolic fractionation of stable carbon isotopes: implications of different proximate compositions for studies of the aquatic food webs using $\delta^{13} \mathrm{C}$ data. Oecologia 115, 337-343.

Frandsen, R.P., Dolmer, P., 2002. Effects of substrate type on growth and mortality of blue mussels (Mytilus edulis) exposed to the predator Carcinus maenas. Marine Biology 141, 253 262.

Frankignoulle, M., Abril, G., Borges, A.V., Bourge, I., Canon, C., Delille, B., Libert, E., Théate, J.-M., 1998. Carbon dioxide emission from European estuaries. Science 282, 434-436.

Frankignoulle, M., Borges, A.V., 2001. Direct and indirect $\mathrm{pCO}_{2}$ measurements in a wide range of $\mathrm{pCO}_{2}$ and salinity values (the Scheldt estuary). Aquatic Geochemistry 7, 267273.

Fry, B., 2002. Conservative mixing of stable isotopes across estuarine salinity gradients: a conceptual framework for monitoring watershed influences on downstream fisheries production. Estuaries 25, 264-271.

Fry, B., Sherr, E.B., 1984. ${ }^{13} \mathrm{C}$ measurements as indicators of carbon flow in marine and freshwater ecosystems. Contribution to Marine Science 27, 13-47.

Furla, P., Galgani, I., Durand, I., Allemand, D., 2000. Sources and mechanisms of inorganic carbon transport for coral calcification and photosynthesis. Journal of Experimental Biology 203, 3445-3457.

Gieskes, W.W.C., Kraay, G.W., Nontji, A., Setiapennana, D., Sutomo, A.B., 1988. Monsoonal alternation of a mixed and layered structure in the phytoplankton of the euphotic zone of the Banda Sea (Indonesia), a mathematical analysis of algal pigment fingerprints. Netherlands Journal of Sea Research 22, 123-137.

Gillikin, D.P., 2005. Geochemistry of Marine Bivalve Shells: the potential for paleoenvironmental reconstruction. Ph.D. thesis. Vrije Universiteit Brussel, Belgium, p. 258.

Gillikin, D.P., De Ridder, F., Ulens, H., Elskens, M., Keppens, E., Baeyens, W., Dehairs, F., 2005a. Assessing the reproducibility and reliability of estuarine bivalve shells (Saxidomus giganteus) for sea surface temperature reconstruction: implications for paleoclimate studies. Palaeogeography Palaeoclimatology Palaeoecology 228, 70-85.
Gillikin, D.P., Lorrain, A., Navez, J., Taylor, J.W., André, L. Keppens, E., Baeyens, W., Dehairs, F., 2005b. Strong biological controls on $\mathrm{Sr} / \mathrm{Ca}$ ratios in aragonitic marine bivalve shells. Geochemistry, Geophysics, Geosystems 6, Q05009. doi:10.1029/2004GC000874.

Gillikin, D.P., Dehairs, F., Lorrain, A., Steenmans, D., Baeyens, W., André, L., 2006. Barium uptake into the shells of the common mussel (Mytilus edulis) and the potential for estuarine paleo-chemistry reconstruction. Geochimica et Cosmochimica Acta 70, 395-407.

Hellings, L., Dehairs, F., Tackx, M., Keppens, E., Baeyens, W., 1999. Origin and fate of organic carbon in the freshwater part of the Scheldt Estuary as traced by stable carbon isotopic composition. Biogeochemistry 47, 167-186.

Hellings, L., Dehairs, F., Van Damme, S., Baeyens, W., 2001. Dissolved inorganic carbon in a highly polluted estuary (the Scheldt). Limnology and Oceanography 46, 1406-1414.

Henry, R.P., Saintsing, D.G., 1983. Carbonic-anhydrase activity and ion regulation in 3 species of osmoregulating bivalve mollusks. Physiological Zoology 56, 274-280.

Herman, P.M.J., Middelburg, J.J., Widdows, J., Lucas, C.H., Heip, C.H.R., 2000. Stable isotopes as trophic tracers: combining field sampling and manipulative labeling of food resources for macrobenthos. Marine Ecology Progress Series 204, 79-92.

Hinga, K.R., Arthur, M.A., Pilson, M.E.Q., Whitaker, D., 1994 Carbon isotope fractionation by marine phytoplankton in culture: the effects of $\mathrm{CO}_{2}$ concentration, $\mathrm{pH}$, temperature, and species. Global Biogeochemical Cycles 8, 91-102.

Hummel, H., Fortuin, A.W., Bogaards, R.H., Wolf, L., de Meijboom, A., 1989. Changes in Mytilus edulis in relation to short-term disturbances of the tide. In: Klekowski, R., Styczynska-Jurewicz, E., Falkowski, L. (Eds.), Proceedings of the 21st European Marine Biological Symposium, Warsaw, Ossolineum, pp. 77- 89.

Kaandorp, R.J.G., Vonhof, H.B., Del Busto, C., Wesselingh, F.P., Ganssen, G.M., Marmol, A.E., Pittman, L.R., van Hinte, J.E., 2003. Seasonal stable isotope variations of the modern Amazonian freshwater bivalve Anodontites trapesialis. Palaeogeography Palaeoclimatology Palaeoecology 194, 339-354.

Kennedy, H., Richardson, C.A., Duarte, C.M., Kennedy, D.P., 2001. Oxygen and carbon stable isotopic profiles of the fan mussel, Pinna nobilis, and reconstruction of sea surface temperatures in the Mediterranean. Marine Biology 139, $1115-1124$.

Killingley, J.S., Berger, W.H., 1979. Stable isotopes in a mollusc shell: detection of upwelling events. Science 205, 186188.

Klein, R.T., Lohmann, K.C., Thayer, C.W., 1996. Bivalve skeletons record sea-surface temperature and $\delta^{18} \mathrm{O}$ via $\mathrm{Mg} /$ $\mathrm{Ca}$ and ${ }^{18} \mathrm{O} /{ }^{16} \mathrm{O}$ ratios. Geology 2, 415-418.

Lehane, C., Davenport, J., 2002. Ingestion of mesozooplankton by three species of bivalve; Mytilus edulis, Cerastoderma edule and Aequipecten opercularis. Journal of the Marine Biological Association of the United Kingdom 82, 615-619.

Lehane, C., Davenport, J., 2004. Ingestion of bivalve larvae by Mytilus edulis: experimental and field demonstrations of larviphagy in farmed blue mussels. Marine Biology 145, 101-107.

Levinton, J.S., Ward, J.E., Shumway, S.E., 2002. Feeding responses of the bivalves Crassostrea gigas and Mytilus 
trossulus to chemical composition of fresh and aged kelp detritus. Marine Biology 141, 367-376.

Lorrain, A., Paulet, Y.-M., Chauvaud, L., Savoye, N., Donval, A., Saout, C., 2002. Differential delta C-13 and delta N-15 signatures among scallop tissues: implications for ecology and physiology. Journal of Experimental Marine Biology and Ecology 275, 47-61.

Lorrain, A., Savoye, N., Chauvaud, L., Paulet, Y.-M., Naulet, N., 2003. Decarbonation and preservation method for the analysis of organic $\mathrm{C}$ and $\mathrm{N}$ contents and stable isotope ratios of low-carbonated suspended particulate material. Analytica Chimica Acta 491, 125-133.

Lorrain, A., Paulet, Y.-M., Chauvaud, L., Dunbar, R., Mucciarone, D., Fontugne, M., 2004. $\delta^{13} \mathrm{C}$ variation in scallop shells: increasing metabolic carbon contribution with body size? Geochimica et Cosmochimica Acta 68, 3509-3519.

Lorrain, A., Gillikin, D.P., Paulet, Y.-M., Chauvaud, L., Le Mercier, A., Navez, J., André, L., 2005. Strong kinetic effects on $\mathrm{Sr} / \mathrm{Ca}$ ratios in the calcitic bivalve Pecten maximus. Geology 33, 965-968.

McConnaughey, T.A., 1989a. ${ }^{13} \mathrm{C}$ and ${ }^{18} \mathrm{O}$ isotope disequilibria in biological carbonates. 1. Patterns. Geochimica et Cosmochimica Acta 53, 151-162.

McConnaughey, T.A., 1989b. ${ }^{13} \mathrm{C}$ and ${ }^{18} \mathrm{O}$ isotopic disequilibrium in biological carbonates: 2 . In vitro simulation of kinetic isotope effects. Geochimica et Cosmochimica Acta 53, 163171.

McConnaughey, T.A., Burdett, J., Whelan, J.F., Paull, C.K., 1997. Carbon isotopes in biological carbonates: respiration and photosynthesis. Geochimica et Cosmochimica Acta 61, 611-622.

McCutchan, J.H., Lewis, W.M., Kendall, C., McGrath, C.C., 2003. Variation in trophic shift for stable isotope ratios of carbon, nitrogen, and sulfur. Oikos 102, 378-390.

Middelburg, J.J., Barranguet, C., Boschker, H.T.S., Herman, P.M.J., Moens, T., Heip, C.H.R., 2000. The fate of intertidal microphytobenthos carbon: an in situ C-13-labeling study. Limnology and Oceanography 45, 1224-1234.

Middelburg, J.J., Nieuwenhuize, J., 1998. Carbon and nitrogen stable isotopes in suspended matter and sediments from the Schelde Estuary. Marine Chemistry 60, 217-225.

Miyajima, T., Yamada, Y., Hanba, Y.T., Yoshii, K., Koitabashi, T., Wada, E., 1995. Determining the stable-isotope ratio of total dissolved inorganic carbon in lake water by $\mathrm{GC} / \mathrm{C} /$ IRMS. Limnology and Oceanography 40, 994-1000.

Mook, W.G., 1971. Paleotemperatures and chlorinities from stable carbon and oxygen isotopes in shell carbonate. Palaeogeography Palaeoclimatology Palaeoecology 9, 245-263.

Mook, W.G., Tan, F.C., 1991. Stable carbon isotopes in rivers and estuaries. In: Degens, E.T., Kempe, S., Richey, J.E. (Eds.), Biogeochemistry of Major World Rivers. John Wiley and Sons Ltd, pp. 245-264.

Mook, W.G., Vogel, J.C., 1968. Isotopic equilibrium between shells and their environment. Science 159, 874-875.

Morton, B., 1992. The evolution and success of the heteromyarian form in the Mytiloida. In: Gosling, E. (Ed.), The Mussel Mytilus: Ecology, Physiology, Genetics and Culture, Developments in Aquaculture and Fisheries Science, vol. 25. Elsevier, pp. 21-52.

Newell, R.I.E., 1989. Species profiles: life histories and environmental requirements of coastal fishes and invertebrates (North - Mid-Atlantic). Blue Mussel. U.S. Fisheries and
Wildlife Service, Biological Report 82(11.102). U.S. Army Corps of Engineers, TR EL-82-4, p. 25. Available at: http:// www.nwrc.usgs.gov/wdb/pub/0169.pdf.

Paneth, P., O'Leary, M.H., 1985. Carbon isotope effect on dehydration of bicarbonate ion catalyzed by carbonic-anhydrase. Biochemistry 24, 5143-5147.

Pocker, Y., Tanaka, N., 1978. Inhibition of carbonic-anhydrase by anions in carbon dioxide-bicarbonate system. Science 199, 907-909.

Post, D.M., 2002. Using stable isotopes to estimate trophic position: models, methods, and assumptions. Ecology 83, 703-718.

Rau, G.H., Takahashi, T., Des Marais, D.J., Repeta, K.J., Martin, J.H., 1992. The relationship between $\delta^{13} \mathrm{C}$ of organic matter and $\left[\mathrm{CO}_{2}(\mathrm{aq})\right]$ in ocean surface water: data from a JGOFS site in the northeast Atlantic Ocean and a model. Geochimica et Cosmochimica Acta 56, 1413-1419.

Roditi, H.A., Fisher, N.S., Sanudo-Wilhelmy, S.A., 2000. Uptake of dissolved organic carbon and trace elements by zebra mussels. Nature 407, 78-80.

Romanek, C.S., Grossman, E.L., Morse, J.W., 1992. Carbon isotopic fractionation in synthetic aragonite and calcite: effects of temperature and precipitation rate. Geochimica et Cosmochimica Acta 56, 419-430.

Savoye, N., Aminot, A., Treguer, P., Fontugne, M., Naulet, N., Kerouel, R., 2003. Dynamics of particulate organic matter $\delta^{15} \mathrm{~N}$ and $\delta^{13} \mathrm{C}$ during spring phytoplankton blooms in a macrotidal ecosystem (Bay of Seine, France). Marine Ecology-Progress Series 255, 27-41.

Shanahan, T.M., Pigati, J.S., Dettman, D.L., Quade, J., 2005. Isotopic variability in the aragonite shells of freshwater gastropods living in springs with nearly constant temperature and isotopic composition. Geochimica et Cosmochimica Acta 69, 3949-3966.

Stecher, H.A., Krantz, D.E., Lord, C.J., Luther, G.W., Bock, K.W., 1996. Profiles of strontium and barium in Mercenaria mercenaria and Spisula solidissima shells. Geochimica et Cosmochimica Acta 60, 3445-3456.

Steffani, C.N., Branch, G.M., 2003. Growth rate, condition, and shell shape of Mytilus galloprovincialis: responses to wave exposure. Marine Ecology-Progress Series 246, 197209.

Swart, P.K., 1983. Carbon and oxygen isotope fractionation in Scleractinian corals: a review. Earth-Science Reviews 19, 5180.

Swart, P.K., Szmant, A., Porter, J.W., Dodge, R.E., Tougas, J.I., Southam, J.R., 2005. The isotopic composition of respired carbon dioxide in scleractinian corals: implications for cycling of organic carbon in corals. Geochimica et Cosmochimica Acta 69, 1495-1509.

Tanaka, N., Monaghan, M.C., Rye, D.M., 1986. Contribution of metabolic carbon to mollusk and barnacle shell carbonate. Nature 320, 520-523.

Tieszen, L.L., Boutton, T.W., Tesdahl, K.G., Slade, N.A., 1983. Fractionation and turn-over of stable carbon isotopes in animal tissues: implications for $\delta^{13} \mathrm{C}$ analysis of diet. Oecologia 57, 32-37.

Vander Putten, E., Dehairs, F., Keppens, E., Baeyens, W., 2000. High resolution distribution of trace elements in the calcite shell layer of modern Mytilus edulis: environmental and biological controls. Geochimica et Cosmochimica Acta 64, 997-1011. 
Verheyden, A., Helle, G., Schleser, G.H., Dehairs, F., Beeckman, H., Koedam, N., 2004. Annual cyclicity in high-resolution stable carbon and oxygen isotope ratios in the wood of the mangrove tree Rhizophora mucronata. Plant, Cell and Environment 27, 1525-1536.

Wang, S., Hong, H., Wang, X., 2005. Bioenergetic responses in green lipped mussels (Perna viridis) as indicators of pollution stress in Xiamen coastal waters, China. Marine Pollution Bulletin 51, 738-743.
Ward, J.E., Shumway, S.E., 2004. Separating the grain from the chaff: particle selection in suspension- and deposit-feeding bivalves. Journal of Experimental Marine Biology and Ecology 300, 83-130.

Wong, W.H., Levinton, J.S., Twining, B.S., Fisher, N.S., Kelaher, B.P., Alt, A.K., 2003. Assimilation of carbon from a rotifer by the mussels Mytilus edulis and Perna viridis: a potential food-web link. Marine Ecology-Progress Series 253, 175-182. 